Tohoku J. Exp. Med., 2005, 207, 293-301

\title{
Inflammatory Mediators Down-Regulate $11 \beta$-Hydroxysteroid Dehydrogenase Type 2 in a Human Lung Epithelial Cell Line BEAS-2B and the Rat Lung
}

\author{
Satoshi Suzuki, Hiroyoshi Tsubochi, Hironori Ishibashi, Yasushi Matsuda, \\ Takashi Suzuki, ${ }^{1}$ Zygmunt S. Krozowski, ${ }^{2}$ Hironobu Sasano ${ }^{1}$ and \\ TAKASHI KONDO \\ Department of Thoracic Surgery, Institute of Development, Aging and Cancer, \\ Tohoku University, Sendai, Japan, \\ ${ }^{1}$ Department of Pathology, Tohoku University School of Medicine, Sendai, \\ Japan, and \\ ${ }^{2}$ Laboratory of Molecular Hypertension, Baker Medical Research Institute, \\ Melbourne, Australia
}

Suzuki, S., Tsubochi, H., Ishibashi, H., Matsuda, Y., Suzuki, T., Krozowski, Z.S., SASAno, H. and Kondo, T. Inflammatory Mediators Down-Regulate 11 $\beta$-Hydroxysteroid Dehydrogenase Type 2 in a Human Lung Epithelial Cell Line BEAS-2B and the Rat Lung. Tohoku J. Exp. Med., 2005, 207 (4), 293-301 — In the lung, anti-inflammatory actions of glucocorticoids would be determined by $11 \beta$-hydroxysteroid dehydrogenase type 2 $(11 \beta$-HSD2), the microsomal enzyme responsible for the breakdown of bio-active glucocorticoids. However, regulation of $11 \beta$-HSD2 under inflammatory conditions such as acute lung injury is not well understood. In the present study, we examined whether inflammatory substances would influence the activity and mRNA expression of $11 \beta$-HSD2 in the lung. In a human bronchial epithelial cell line BEAS-2B, endotoxin inhibited $11 \beta$-HSD2 enzyme activity in a dose-dependent manner over $48 \mathrm{~h}$ with a significant decrease in the mRNA expression. Likewise, tumor necrosis factor (TNF)- $\alpha$ inhibited both activity and mRNA expression of $11 \beta$-HSD2. The TNF- $\alpha$-dependent decrease in the enzyme activity was completely blocked by anti-TNF- $\alpha$ antibody, while antibody alone showed no significant influence on the enzyme activity. An nitric oxide donor (NO) sodium nitropusside or a cGMP analog 8-br-cGMP caused moderate but significant decreases in both activity and mRNA expression of $11 \beta$-HSD2. Importantly, treatment of rats with endotoxin significantly decreased both activity and mRNA expression of $11 \beta$-HSD2 in the lung tissue. We conclude that lung inflammation reduces local glucocorticoid breakdown and augments glucocorticoid action in the lung by down-regulating $11 \beta$-HSD2 via multiple mechanisms. - 11 $\beta$-hydroxysteroid dehydrogenase type 2 ; endotoxin; inflammation; acute lung injury; glucocorticoids

(C) 2005 Tohoku University Medical Press

Received August 18, 2005; revision accepted for publication September 16, 2005.

Correspondence: Satoshi Suzuki, M.D., Department of Thoracic Surgery, Institute of Development, Aging and Cancer, Tohoku University, 4-1 Seiryomachi, Aoba-ku, Sendai 980-8575, Japan.

e-mail: satoshisuzuki@idac.tohoku.ac.jp 
Under systemic inflammatory conditions such as sepsis, acute lung injury becomes the most critical complication with very high mortality rate. The pathophysiology of acute lung injury is currently considered to be an inflammatory burst in the lung where a wide variety of inflammatory substances are produced.

At present, glucocorticoids are one of the most effective therapeutic agents for lung inflammation. In fact, systemic and/or inhaled glucocorticoid therapy demonstrates great clinical benefits in several lung inflammatory conditions such as bronchial asthma (Ichinose 2003). However, the efficacy of glucocorticoid therapy in acute lung injury is less significant and still a controversial issue (Thompson 2003), although synthetic glucocorticoids are frequently introduced to patients with acute lung injury.

Although both natural and synthetic glucocorticoids exert their powerful anti-inflammatory actions via glucocorticoid receptor (GR) in the target cells, it is important that local glucocorticoid actions would be in part determined by $11 \beta$-hydroxysteroid dehydrogenase (11 $\beta$-HSD), the microsomal enzyme responsible for the breakdown of bio-active glucocorticoids to their receptor-inactive forms. To date, two distinct isofoms of $11 \beta$-HSD have been cloned and characterized in several species including humans (Stewart and Krozowski 1999). 11 $\beta$-HSD1 enzyme requires $\mathrm{NADP}^{+}$as a cofactor and possesses both reductase and dehydrogenase activity. In contrast, the type 2 isoform $\left(11 \beta\right.$-HSD2) requires $\mathrm{NAD}^{+}$as a cofactor and possesses only dehydrogenase activity. It was reported that adult human lung homogenates displayed $\mathrm{NAD}^{+}$-dependent glucocorticoid conversion, suggesting the presence of $11 \beta$-HSD2 (Murphy 1978). Our recent immunohistochemical examinations in human lung tissues have revealed that bronchial epithelial cells express $11 \beta$-HSD2, but not $11 \beta$-HSD1 (Suzuki et al. 1998).

$11 \beta$-HSD2 may be regulated via multiple mechanisms. It has been shown that glucocorticoids increase the expression of $11 \beta$-HSD2 mRNA in endometrial cells (Darnel et al. 1999). We have recently shown that a therapeutic dose of glucocorticoids is sufficient to up-regulate $11 \beta$-HSD2 in a human bronchial epithelial cell line BEAS-2B (Suzuki et al. 2003). In contrast, tumor necrosis factor (TNF)- $\alpha$ possesses a strong inhibitory action on $11 \beta$-HSD2 (Heiniger et al. 2001). Interestingly, nitric oxide (NO) may also influence $11 \beta$-HSD2 (Sun et al. 1997). We therefore wished to know whether $11 \beta$-HSD2 would be inhibited directly or indirectly by inflammatory substances such as endotoxin, which plays an important role in the pathophysiology of acute lung injury. In the present study, we examined the effects of endotoxin or its related inflammatory mediators, TNF- $\alpha$ and NO, on the enzyme activity and mRNA expression of $11 \beta$-HSD2 in a human bronchial epithelial cell line BEAS-2B (Reddel et al. 1988). In addition, we investigated the effect of in vivo treatment with endotoxin on $11 \beta$-HSD2 in the rat lung.

\section{Materials ANd Methods}

\section{Cell culture}

BEAS-2B cells (American Type Culture Collection, Manassas, VA, USA) were cultured in Dulbecco's modified Eagle's Medium/F12-medium (GIBCO-BML, Rockville, MD, USA) supplemented with $10 \%$ fetal bovine serum (FBS; GIBCO-BML) on 6-well plastic plates at $37^{\circ} \mathrm{C}$ in a humidified $95 \%$ air- $5 \% \mathrm{CO}_{2}$ incubator. BEAS-2B is an established cell line derived from normal human bronchial epithelial cells transformed with an adenovirus and retains electron microscopic features of epithelial cells (Reddle et al. 1988). Cells were grown to $80-90 \%$ confluency before being cultured in serumfree medium $24 \mathrm{~h}$ prior to treatment. Cells were then exposed to endotoxin (O55:B5 Escherichia coli; Calbiochem, La Jolla, CA, USA) for up to $48 \mathrm{~h}$. Cells were also exposed to human TNF- $\alpha$ (Boeringer Mannheim, Mannheim, Germany) in the presence or absence of $10 \mu \mathrm{g} / \mathrm{ml}$ of anti-human TNF- $\alpha$ antibody (R \& D Systems, Minneapolis, MN, USA). In addition, the effect of NO was studied by incubating the cells with sodium nitroprusside (SNP; Sigma, St. Louis, MO, USA), 8-bromo-guanosin 3'; 5'-cyclic monophosphate (8-br-cGMP; Sigma) or L-arginine (Sigma) for $24 \mathrm{~h}$. Once it was clear that endotoxin, TNF- $\alpha$, SNP or 8-brcGMP, but not L-arginine, showed significant inhibitory actions on $11 \beta$-HSD2, it became interesting whether the effect of endotoxin was mediated via NO, which could 
be produced via inducible NO synthase (iNOS) by endotoxin in a very short period of time. We therefore determined $11 \beta$-HSD2 enzyme activity in the presence of 0.1 $\mathrm{mM}$ of aminoguanidine (Sigma), a potent inhibitor of iNOS (Misko et al. 1993).

\section{Animal preparation}

To investigate the in vivo effects of endotoxin on lung $11 \beta$-HSD2, specific pathogen free male SpragueDawley rats weighing 280-300 g were used ( $n=9)$. All animals received humane care in compliance with the guideline from the University Committee on Animal Resources, Tohoku University. The animal experiments were conducted in accordance with the "Principle of Laboratory Animal Care" formulated by the Intitute of Laboratory Animal Resources and the "Guide for the Care and Use of laboratory Animals" prepared by the Institute of Laboratory Animal Resources and published by the National Institute of Health (NIH Publication No. $86-23,1985)$. The protocol of this study was reviewed and approved by the Committee for Animal Research Ethics, Tohoku University. Rats were lightly anesthetized with pentobarbital sodium $(15 \mathrm{mg} / \mathrm{kg}$, intraperitoneal injection), and then endotoxin $(1.0 \mathrm{mg} / \mathrm{kg})$ suspended in $0.2 \mathrm{ml}$ of sterilized saline was introduced directly into the trachea via a 26-gauge needle. To examine whether endotoxin influenced $11 \beta$-HSD2 via iNOS, rats $(n=3)$ were treated with a subcutaneus injection of 75 $\mathrm{mg} / \mathrm{kg}$ of aminoguanidine in $0.5 \mathrm{ml}$ of sterilized saline 10 min before endotoxin instillation (Tsubochi et al. 2003). At $24 \mathrm{~h}$ following endotoxin instillation, rats were sacrificed by deep anesthesia with pentobarbital sodium (50 $\mathrm{mg} / \mathrm{kg}$, intraperitoneal injection). Lung tissue samples were dissected and immediately frozen in liquid nitrogen. The tissue samples were kept at $-80^{\circ} \mathrm{C}$ until protein and mRNA extractions.

\section{Steroid conversion assay}

Cultured cells. To measure 11 $\beta$-HSD2 enzyme activity in intact BEAS-2B cells, cell monolayers were washed with phosphate buffered saline (PBS) and incubated with serum-free medium containing $2 \mathrm{nM}$ of $\left[{ }^{3} \mathrm{H}\right]$ cortisol (New England Nuclear, Boston, MA, USA) at $37^{\circ} \mathrm{C}$ for $8 \mathrm{~h}$. The steroids were extracted into ethanol containing unlabelled cortisol (F) (Sigma) and cortisone (E) (Sigma), and then separated on plastic silica gel plates using chloroform/ethanol (92:8) as a solvent (Smith et al. 1997). Areas corresponding to cold carriers were visualized under UV light, cut out into scintillation

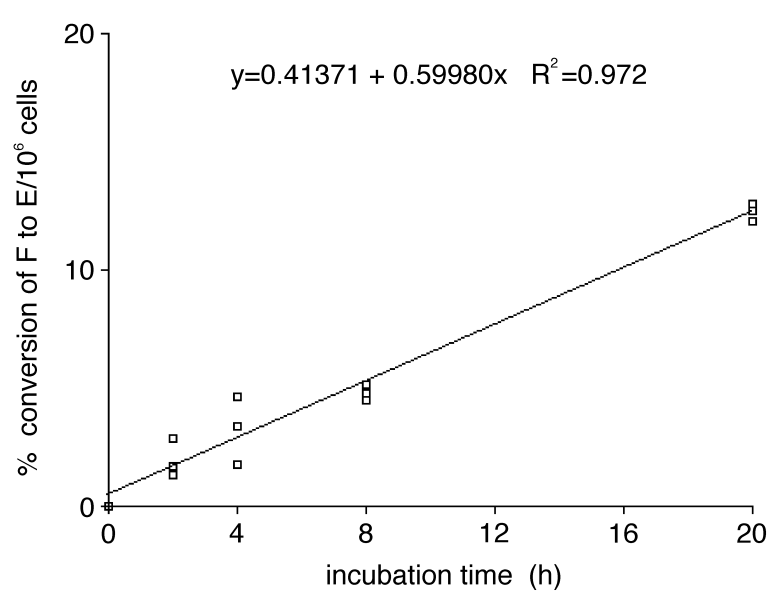

Fig. 1. Time course of steroid conversion in BEAS2B cells. The cells were incubated with serumfree medium containing $2 \mathrm{nM}$ of $\left[{ }^{3} \mathrm{H}\right]$-cortisol. The steroids conversion from cortisol (F) to cortisone (E) in BEAS-2B cells was linear over $20 \mathrm{~h}$. The steroid concentration in the cell culture medium was standardized to cell counts and expressed as percent conversion of $\mathrm{F}$ to $\mathrm{E} / \mathrm{h} / 10^{6}$ cells. The number of measurements at each incubation period of time was three.

vials, and counted in a $\beta$-counter. $11 \beta$-HSD2 enzyme activity was expressed as percent conversion of $\mathrm{F}$ to $\mathrm{E} / \mathrm{h} / 10^{6}$ cells. The steroid conversion in BEAS-2B cells was linear over $20 \mathrm{~h}$ (Fig. 1).

Lung tissues. Rat lung tissue samples were homogenized in a homogenate buffer $(140 \mathrm{mM} \mathrm{NaCl}, 250 \mathrm{mM}$ sucrose, $10 \mathrm{mM}$ sodium phosphate buffer, $\mathrm{pH}$ 7.4) on ice using a rotor homogenizer for three 20 -sec periods on ice. Whole lung homogenates (100 $\mu \mathrm{g}$ protein) were incubated with $2 \mathrm{nM}$ of $\left[{ }^{3} \mathrm{H}\right]$-corticosterone (New England Nuclear) in the presence or absence of $0.5 \mathrm{mM} \mathrm{NAD}^{+}$ (Sigma) at $37^{\circ} \mathrm{C}$ for $4 \mathrm{~h}$. The enzyme reaction was terminated by the addition of ethyl acetate. The steroids were extracted into ethanol containing unlabelled corticosterone (B) (Sigma) and 11-hydroxycorticosterone (A) (Sigma), separated, and counted as described above. Results were expressed as percent conversion of B to $\mathrm{A} / \mathrm{h} / \mathrm{mg}$ lung protein.

Quantitative transcription-polymerase chain reaction (RT-PCR)

Total RNA was extracted from BEAS-2B cells and rat lung samples using an RNA isolation reagent (RNABee, Tel-Test, Friendwood, TX, USA) according to the 
manufacturer's protocols. In BEAS-2B cells, cDNA for human $11 \beta$-HSD2 was synthesized from $5 \mu \mathrm{g}$ of total RNA using a reverse transcription kit (SUPERSCRIPT Preamplification system, GIBCO-BRL). PCR of cDNA was carried out by a real-time PCR with the Light Cycler System (Roch Diagnostics, Mannheim, Germany) using the DNA binding dye SYBER Green I (Roch Diagnostics) at $95^{\circ} \mathrm{C}$ for $1 \mathrm{~min}$, followed by 40 cycles at $95^{\circ} \mathrm{C} 15 \mathrm{sec}$, annealing at $60^{\circ} \mathrm{C}$ and extension for $15 \mathrm{sec}$ at $72^{\circ} \mathrm{C}$. The oligonucleotide primers were: human 11 $\beta$-HSD2 (Pasqurette et al. 1996), 5'-CAG ATG GAC CTG ACC AAA CC-3' (forward), 5'-GCC AAA GAA ATT CAC CTC CA-3' (reverse); human glyceraldehyde3-phosphate dehydrogenase (GAPDH), 5'-TGA ACG GGA AGC TCA CTG G-3' (forward), 5'-TCC ACC ACC CTG TTG CTG TA-3' (reverse). In rat lung tissue samples, cDNA for rat $11 \beta$-HSD2 was synthesized from $50 \mathrm{ng}$ of total RNA. PCR of cDNA was performed with a one-step RT-PCR reagent kit (TaqMan One-Step RTPCR Master Mix Reagent, Applied Biosystems, Tokyo) at $48^{\circ} \mathrm{C}$ for $30 \mathrm{~min}, 95^{\circ} \mathrm{C}$ for $10 \mathrm{~min}$, and 40 cycles at $95^{\circ} \mathrm{C}$ for $15 \mathrm{sec}$ and $60^{\circ} \mathrm{C}$ for $1 \mathrm{~min}$ in a sequence detection system (ABI PRISM 7700, Applied Biosystems). The forward and reverse primers and TaqMan probes for rat 11 $\beta$-HSD2 (Zhou et al. 1995) were; 5'-TTT GGC AAG GAG ACA GCT AAG AA-3' (forward), 5'-ATC

A

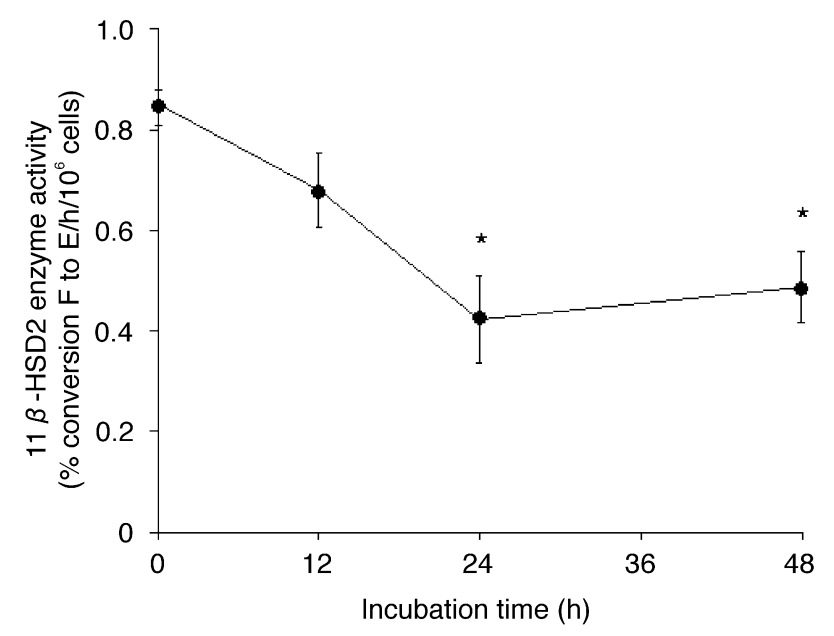

CAA CAC AGT GGC CAG C-3’ (reverse), 5'-CTG GAT GCC ATG GGC TTC ACG G-3’ (TaqMan probe). Primers and TaqMan probe for rodent ribosome RNA (Applied Biosystems) was used an internal standard. Results were expressed in the ratio to either GAPDH or ribosome RNA in same RNA samples, and expressed percentage of the control values.

\section{Statistical analysis}

Results were presented as mean \pm S.D. Comparisons between groups were performed by analysis of variance (ANOVA). When significant difference was found initially by ANOVA, it was followed by a Bonferroni adjustment to identify which groups were significantly different. $P<0.05$ was considered statistically significant.

\section{Results}

Endotoxin inhibited $11 \beta$-HSD2 enzyme activity in BEAS-2B cells in a dose-dependent manner, and only $50 \%$ of enzyme activity was measured in the cells treated with $1 \mu \mathrm{g} / \mathrm{ml}$ of endotoxin for $24 \mathrm{~h}$ (Fig. 2). TNF- $\alpha$ also inhibited $11 \beta$-HSD2 enzyme activity (Fig. 3 ). The effect of TNF- $\alpha$ on $11 \beta$-HSD2 enzyme activity was completely blocked by anti-TNF- $\alpha$ antibody, while

B

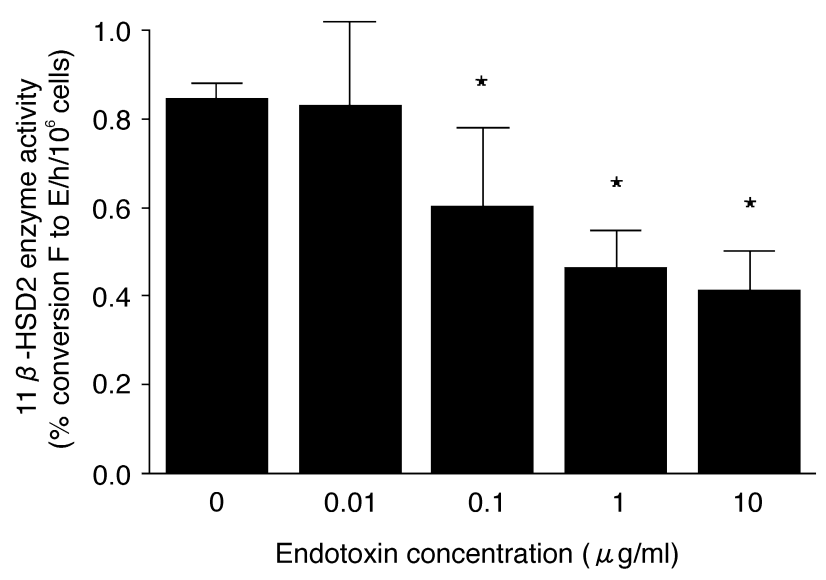

Fig. 2. Effect of endotoxin on $11 \beta$-HSD2 enzyme activity in BEAS-2B cells. A: Time course. The decrease in $11 \beta$-HSD2 enzyme activity was observed with $1 \mu \mathrm{g} / \mathrm{ml}$ of endotoxin after $24 \mathrm{~h}$ of incubation. B: Dose. Enzyme activity of $11 \beta$-HSD2 was inhibited to almost $50 \%$ at the dose starting from $1 \mu \mathrm{g} / \mathrm{ml}$ of endotoxin at $24 \mathrm{~h}$. Results are shown as mean \pm S.D. for five separate experiments. ${ }^{*} p<0.05$ vs the values at time 0 (A) or the values determined without endotoxin (B) by ANOVA followed by a Bonferroni adjustment. 
antibody alone showed no significant influence on the enzyme activity (Fig. 4). In contrast, the endotoxin-mediated decrease in $11 \beta$-HSD2 enzyme activity was not attenuated by anti-TNF- $\alpha$ antibody (Fig. 4). Treatment with aminoguanidine, a potent inhibitor of iNOS, did not rescue the decrease of $11 \beta$-HSD2 enzyme activity caused by endotoxin or TNF- $\alpha$ (Fig. 4). An NO donor
A

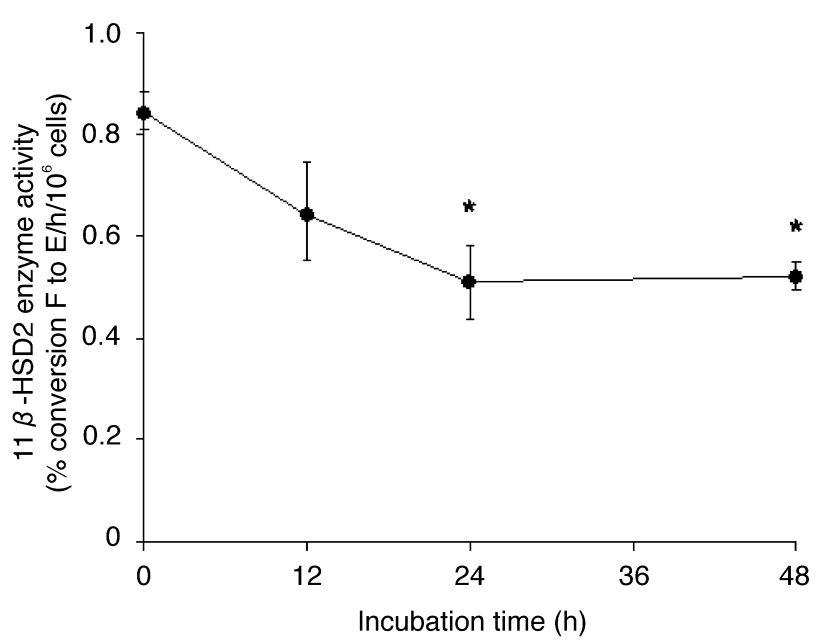

B

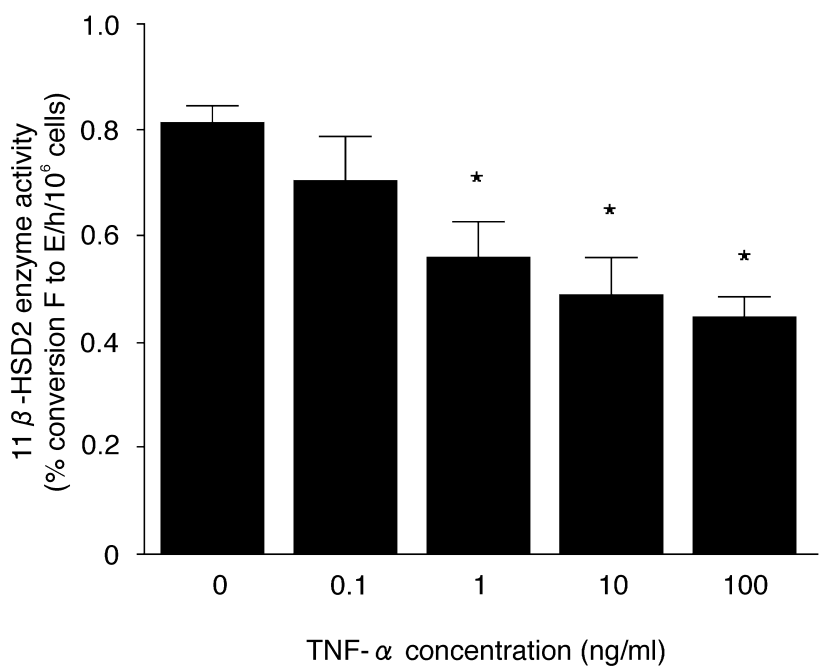

Fig. 3. Effect of TNF- $\alpha$ on $11 \beta$-HSD2 enzyme activity in BEAS-2B cells. A: Time course. The decrease in $11 \beta$-HSD2 enzyme activity was observed with $10 \mathrm{ng} / \mathrm{ml}$ of TNF- $\alpha$ after $24 \mathrm{~h}$ of incubation. B: Dose. Enzyme activity of $11 \beta$-HSD 2 was inhibited to almost $50 \%$ at the dose starting from $10 \mathrm{ng} / \mathrm{ml}$ of TNF- $\alpha$ at $24 \mathrm{~h}$. Results are shown as mean \pm S.D. for five separate experiments. ${ }^{*} p<0.05$ vs the values at time 0 (A) or the values determined without TNF- $\alpha$ (B) by ANOVA followed by a Bonferroni adjustment.

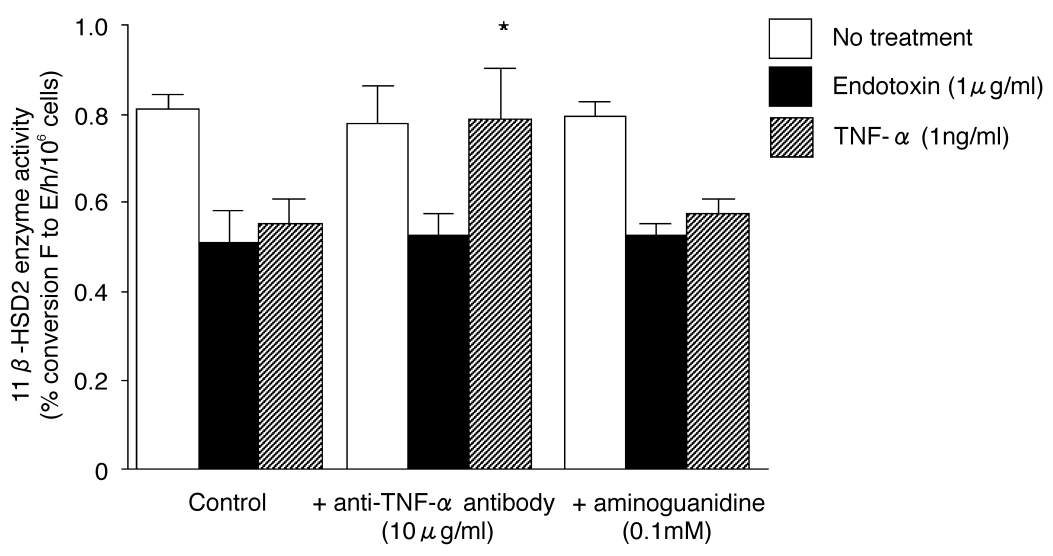

Fig. 4. Effects of anti-TNF- $\alpha$ antibody and aminoguanidine on 11 $\beta$-HSD2 enzyme activity in BEAS-2B cells. Anti-TNF- $\alpha$ antibody $(10 \mu \mathrm{g} / \mathrm{ml})$ ameliorated the TNF- $\alpha$-induced decrease in the enzyme activity $(1 \mathrm{ng} / \mathrm{ml}$ of TNF- $\alpha$ ) completely, however it did not rescue the endotoxin-induced decrease $(1 \mu \mathrm{g} / \mathrm{ml}$ of endotoxin). Anti-TNF- $\alpha$ antibody alone had no influence on the enzyme activity. Aminoguanidine $(0.1 \mathrm{mM})$ did not ameliorate the reduced enzyme activity by endotoxin and TNF- $\alpha$, while aminoguanidine alone had no influence on the enzyme activity. Results are shown as mean \pm S.D. for five separate experiments. ${ }^{*} p<0.05$ vs the values of without antibody treatment by ANOVA followed by a Bonferroni adjustment. 


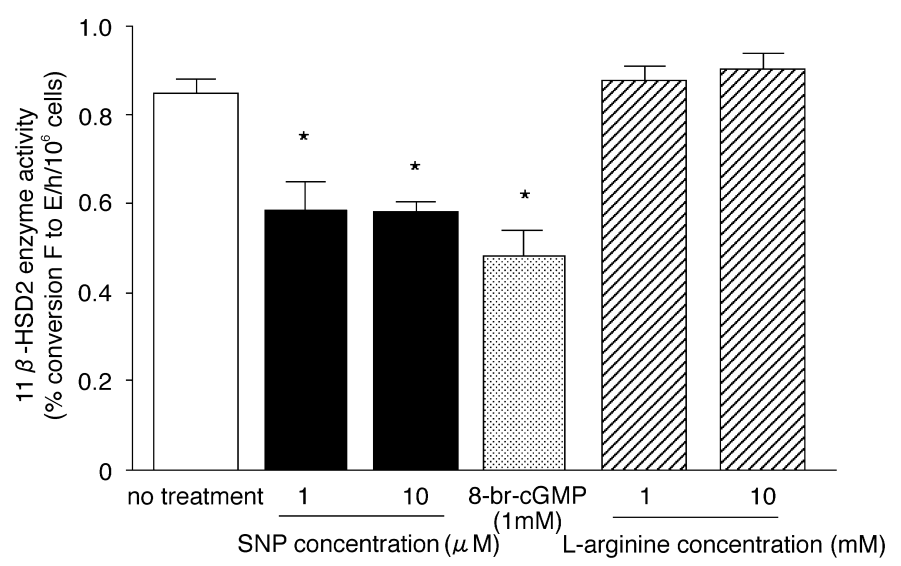

Fig. 5. Effects of SNP, 8-br-cGMP and L-arginine on 11 $\beta$-HSD2 enzyme activity in BEAS-2B cells. An NO donor SNP and a cGMP analog 8-br-cGMP inhibited the enzyme activity to approximately $70 \%$ of control at $24 \mathrm{~h}$. In contrast, incubation with L-arginine did not show significant effects on $11 \beta$-HSD2 enzyme activity even at higher concentrations. Results are shown as mean \pm S.D. for five separate experiments. ${ }^{*} p<0.05$ vs the values of no treatment by ANOVA followed by a Bonferroni adjustment.

TABLE 1. Enzyme activity and mRNA expression of $11 \beta-H S D 2$ in BEAS-2B cells

\begin{tabular}{lcc}
\hline & Enzyme activity & mRNA expression \\
\hline Endotoxin $(10 \mu \mathrm{g} / \mathrm{ml})$ & $48.9 \pm 10.4^{*}$ & $1.1 \pm 0.2^{*}$ \\
$\mathrm{TNF}-\alpha(100 \mathrm{ng} / \mathrm{ml})$ & $55.2 \pm 4.9^{*}$ & $3.0 \pm 0.6^{*}$ \\
SNP $(100 \mu \mathrm{m})$ & $68.5 \pm 3.0^{*}$ & $8.7 \pm 4.1^{*}$ \\
8-br-cGMP $(1 \mathrm{~mm})$ & $61.8 \pm 10.4^{*}$ & $8.9 \pm 3.3^{*}$ \\
L-arginine $(100 \mu \mathrm{m})$ & $118.0 \pm 7.8$ & $103.6 \pm 15.4$ \\
\hline
\end{tabular}

The cells were collected at $24 \mathrm{~h}$ of incubation for steroid conversion assay and mRNA extraction. Data are presented as mean \pm S.D. of the percent values of control ( $n=5$ for enzyme activity, $n=3$ for mRNA expression).

${ }^{*} p<0.05$ vs control by ANOVA followed by Bonferroni adjustment.

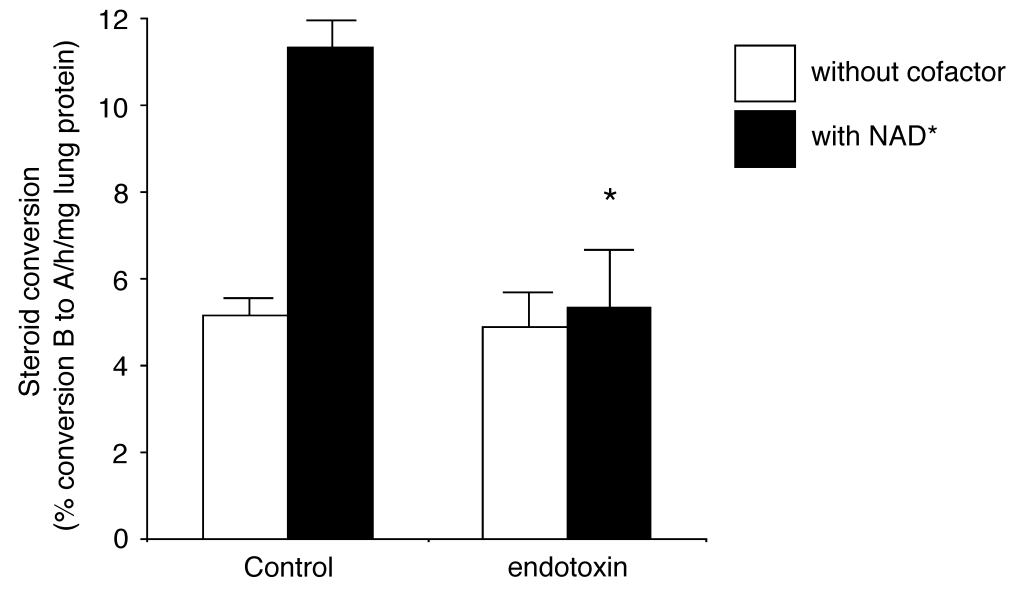

Fig. 6. Effect of endotoxin on $11 \beta$-HSD2 enzyme activity in the rat lung. Endotoxin inhibited the $\mathrm{NAD}^{+}$-dependent steroid conversion. Results are shown as mean \pm S.D. for three separate experiments. $\stackrel{p}{p}<0.05$ vs control values by ANOVA followed by a Bonferroni adjustment. 
SNP inhibited the enzyme activity to approximately $70 \%$ of control values at two different concentrations (1 and $10 \mu \mathrm{M})$ at $24 \mathrm{~h}$ (Fig. 5). A cGMP analog 8-br-cGMP (1 mM) also displayed a similar inhibitory effect (Fig. 5). In contrast, incubation with L-arginine, a substrate for NO synthases (NOS), did not show significant effects on $11 \beta$-HSD 2 enzyme activity at even higher concentrations (1 and $10 \mathrm{mM}$ ) (Fig. 5).

Endotoxin, TNF- $\alpha$, SNP or 8-br-cGMP caused a marked decrease in $11 \beta$-HSD2 mRNA expression in the cells (Table 1). However, only L-arginine, which did not change the enzyme activity, showed no significant influence on the mRNA levels (Table 1).

In rat experiments, all animals survived until the time point of tissue sampling at $24 \mathrm{~h}$ following endotoxin challenge. In the lungs, there was a significant decrease in the $\mathrm{NAD}^{+}$-dependent steroid conversion (Fig. 6). 11 $\beta$-HSD2 mRNA expression was reduced to $35.2 \pm 5.1 \%$ of control values at $24 \mathrm{~h}$ following endotoxin instillation $(n=3)$. Treatment with aminoguanidine did not attenuate the decrease in $11 \beta$-HSD2 enzymatic activity data not shown.

\section{DiscuSsion}

BEAS-2B cells provide a useful tool to investigate lung $11 \beta$-HSD2. This cell line is known to express toll-like receptor (TLR)-4 (Ulevitch and Tobias 1995), thereby endotoxin being capable to activate intracellular signaling cascade such as nuclear factor (NF) $\kappa \mathrm{B}$ (Schultz et al. 2002). Moreover, BEAS-2B cells express $11 \beta$-HSD2, but not its type 1 isoform (Suzuki et al. 2003), although the expression level is not as strong as in primary cultured human bronchial epithelial cells (Feistein and Schleimer 1999). Therefore, only $11 \beta$-HSD2 is responsible for the breakdown of bio-active glucocorticoids ( $F$ to $\mathrm{E}$ ) in BEAS-2B cells.

In this cell line, endotoxin inhibited $11 \beta$-HSD 2 in a dose-dependent manner. Importantly, the decrease in the enzyme activity was associated with a marked decrease in mRNA expression. The greater reduction of mRNA expression, compared to the reduction of enzyme activity, may suggest relatively long turnover rate of $11 \beta$-HSD 2 protein in the cells, although enzyme activity is not simply determined by the protein content. It is noteworthy that the effect of endotoxin was similar in time course and the magnitude to those found with TNF- $\alpha$. Although endotoxin produces TNF- $\alpha$ in BEAS-2B cells, the impact of endotoxin on $11 \beta$-HSD2 may not be mediated by TNF- $\alpha$. First, anti-TNF- $\alpha$ antibody did not attenuate the endotoxin-induced decrease in $11 \beta$-HSD2 enzyme activity. Second, release of TNF- $\alpha$ from BEAS-2B cells requires an increase in mRNA expression that would take several hours after endotoxin challenge. Instead, we believe that TLR-4 after endotoxin binding may share the same intracellular signaling, such as $\mathrm{NF}-\kappa \mathrm{B}$, which also plays a central role after TNF$\alpha$ stimulation.

We found that $11 \beta$-HSD 2 enzyme activity in BEAS-2B cells were reduced by SNP or 8-brcGMP, although the magnitude of reduction seemed somewhat smaller than that of endotoxin. Thus, a next question may arise whether the effects of endotoxin would be mediated via NO. However, it is unlikely that NO is involved in the endotoxin-mediated down-regulation of $11 \beta$-HSD2 in BEAS-2B cells. It was reported that the expression of constitutive NOS was low in BEAS-2B cells (Asano et al. 1994). In the present study, L-arginine, a substrate for NOS, did not show any detectable inhibitory action on $11 \beta$-HSD2. In addition, aminoguanidine, a potent inhibitor of iNOS, did not attenuate the endotoxin-mediated decrease $11 \beta$-HSD2 in the cells. Although NO itself appeared to down-regulate $11 \beta$-HSD2 in the cells, endotoxin challenge alone may not be enough to produce physiologically sufficient amount of NO to influence $11 \beta$-HSD2 in BEAS-2B. It was only when the cells were stimulated by endotoxin combined with various pro-inflammatory cytokines at very high concentrations that iNOS expression in BEAS-2B cells became significant (Watkins et al. 1997).

Our data obtained from cell experiments indicate that inflammatory substances directly influence $11 \beta$-HSD2 in lung epithelial cells. It should be noted that lung tissue is composed of 
more than 40 cell types. It is therefore conceivable that endotoxin might modulate $11 \beta$-HSD2 in the lung via NO, which is released from other cell types such as alveolar macrophages by the endotoxin challenge in a short period of time. We have previously found that low concentration of endotoxin is capable of produce physiologically significant amount of NO via iNOS in alveolar macrophages rather than lung epithelium (Tsubochi et al. 2003). Therefore, we decided to re-examine the effect of endotoxin on $11 \beta$-HSD2 in the presence of aminogianidine in the rat lung. Again we found aminoguanidine did not attenuate the endotoxin-mediated decrease in $11 \beta$-HSD2 enzyme activity in the lung. We have previously reported that in vivo treatment with aminoguanidine at the same dose completely inhibited NO production following endotoxin instillation in rats (Tsubochi et al. 2003). It is also important that endotoxin challenge may elevate circulating glucocorticoid levels in rats. Since natural glucocorticoids are capable to up-regulate $11 \beta$-HSD2 (Suzuki 2003), this may explain in part the difference in the magnitude of the endotoxin-mediated decrease in the mRNA expression between the cell and animal experiments.

Endotoxin initiates multiple intracellular signaling pathways, such as $\mathrm{NF}-\kappa \mathrm{B}$, which plays an important role in the release of a wide array of inflammatory substances including a strong chemoattractant interleukin (IL)-8. This may lead lung inflammation to more serious condition. In addition to the promotion of inflammatory response, our data seem to provide a new concept that inflammation itself may set a feedback system by increasing local glucocorticoid availability. The down-regulation of $11 \beta$-HSD2 means a slower breakdown of bio-active glucocorticoids, thereby increasing their intracellular concentrations at the site of inflammation. An increase in local glucocorticoid availability may then augment anti-inflammatory effects of natural and/or synthetic glucocorticoids. We have recently shown that inhibition of $11 \beta$-HSD2 with carbenoxolone, a synthetic derivative of licorice, potentiates the inhibitory effect of dexamethasone on IL-8 release from the TNF- $\alpha$-stimulated BEAS-
2B cells by about 10 folds (Suzuki et al. 2003). Similar results were reported in primary cultured bronchial epithelial cells (Feinstein and Schleimer 1999). More recently, we found treatment with carbenoxolone augmented anti-inflammatory action of endogenous glucocorticoids in the rat lung (Suzuki et al. 2004). It has been well known that systemic inflammatory condition elevates endogenous glucocorticoid levels in blood via the hypothalamic-pituitary-adrenal axis. In addition to elevated circulating glucocorticoid levels, inflammation may reduce glucocorticoid breakdown and augment local glucocoryicoid antiinflammatory actions by down-regulating lung $11 \beta$-HSD2 via multiple mechanisms.

\section{References}

Asano, K., Chee, C.B.E., Gaston, B., Lilly, C.M., Gerard, C., Drazen, J.M. \& Stamler, J.S. (1994) Constitutive and inducible nitric oxide synthase gene expression, regulation, and activity in human lung epithelial cells. Proc. Natl. Acad. Sci. USA, 91, 10089-10093.

Darnel, A.D., Archer, T.K. \& Yang, K. (1999) Regulation of $11 \beta$-hydroxysteroid dehydrogenase type 2 by steroid hormones and epidermal growth factor in the Ishikawa human endometrial cell line. J. Steroid Biochem. Mol. Biol., 70, 203-210.

Feinstein, M.B. \& Schleimer, R.P. (1999) Regulation of the action of hydrocortisone in airway epithelial cells by $11 \beta$-hydroxysteroid dehydrogenase. Am. J. Respir. Cell Mol. Biol., 21, 403-408.

Heiniger, C.D., Rochat, M.K., Frey, F.J. \& Frey, B.M. (2001) TNF- $\alpha$ enhances intracellular glucocorticoid availability. FEBS Lett., 507, 351-356.

Ichinose, M. (2003) Inflammatory mechanisms in bronchial asthma and COPD. Tohoku J. Exp. Med., 200, 1-6.

Misko, T.P., Moore, W.M., Kastenm T.P,. Nikols, G.A., Corbett, J.A., Tilton, R.G., McDaneil, M.L., Williamson, J.R. \& Currie, M.G. (1993) Selective inhibition of the inducible nitric oxide synthase by aminoguanidine. Eur. J. Pharmacol., 233, 119-125.

Murphy, B.E.P. (1978) Cortisol production and inactivation by the human lung during gestation and infancy. J. Clin. Endocrinol. Metab., 47, 243-248.

Pasqurette, M.M., Stewart, P.M., Ricketts, M.L., Imaishi, K. \& Mason, J.I. (1996) Regulation of $11 \beta$-hydroxysteroid dehydrogenase type 2 activity and mRNA in human choriocarcinoma cells. J. Mol. Endocrinol., 16, 269-275.

Reddle, R.R., Ke, Y., Gerwin, B.I., McMenamin, M.G., Lechner, J.F., Su, R.T., Brash, D.E., Park, J.B., Rhim, J.S. \& Harris, C.C. (1988) Transformation of human bronchial epithelial cells by infection with SV40 or adenovirus-12 SV40 hybrid virus, or tranfection via strontium phosphate coprecipitation with a plasmid containing SV40 early region genes. Cancer Res., 48, 1904-1909.

Schultz, C., Farkas, L., Wolf, K., Krätzel, K., Eissner, G. \& Pfeifer, M. (2002) Differences in LPS-induced activation of bronchial epithelial cells (BEAS-2B) and type II-like 
pneumocytes (A-549). Scand. J. Immunol., 56, 294-302.

Smith, R.E., Li, K.X.Z., Andrews, R.K. \& Krozowski, Z.S. (1997) Immunohistochemical and molecular characterization of the rat $11 \beta$-hydroxysteroid dehydrogenase type II enzyme. Endocrinology., 138, 540-547.

Stewart, P.M. \& Krozowski, Z.S. (1999) 11 $\beta$-hydroxysteroid dehydrogenase. Vitam. Horm., 57, 249-324.

Sun, K., Yang, K. \& Challis, J.R.G. (1997) Differential regulation of $11 \beta$-hydroxysteroid dehydrogenase type 1 and 2 by nitric oxide in cultured human placental trophoblast and chorionic cell preparation. Endocrinology., 138, 4912-4920.

Suzuki, S., Koyama, K., Darnel, A., Ishibashi, H., Kobayashi, S., Kubo, H., Suzuki, T., Sasano, H. \& Krozowski, Z.S. (2003) Dexamethasone upregulates $11 \beta$-hydroxysteroid dehydrogenase type 2 in BEAS-2B cells. Am. J. Respir. Crit. Care Med., 167, 1244-1249.

Suzuki, S., Matsuda, Y., Sugawara, T., Tabata, T., Ishibashi, H., Hoshikawa, Y., Kubo, H. \& Kondo, T. (2004) Effects of carbenoxolone on alveolar fluid clearance and lung inflammation in the rat. Crit. Care Med., 32, 1910-1915.

Suzuki, T., Sasano, H., Suzuki, S., Hirasawa, G., Takeyama, J., Muramatsu, Y., Date, F., Nagura, H. \& Krozowski, Z.S.
(1998) 11 $\beta$-hydroxysteroid dehydrogenase type 2 in human lung: possible regulator of mineralocorticoid action. J. Clin. Endocrinol. Metab., 83, 4022-4025.

Thompson, B.T. (2003) Glucocorticoids and acute lung injury. Crit. Care Med., 31, S253-S257.

Tsubochi, H., Suzuki, S., Kubo, H., Ueno, T., Yoshimura, T., Suzuki, T., Sasano, H. \& Kondo, T. (2003) Early changes in alveolar fluid clearance by nitric oxide after endotoxin instillation in rats. Am. J. Respir. Crit. Care Med., 167, 205-210.

Ulevitch, R.J. \& Tobias, P.S. (1995) Receptor-dependent mechanisms of cell stimulation by bacterial endotoxin. Ann. Rev. Immunol., 13, 437-457.

Watkins. D.N., Peroni, D.J., Basclain, K.A., Garlepp, M.J. \& Thompson, P.J. (1997) Expression and activity of nitric oxide synthases in human airway epithelium. Am. $J$. Respir. Cell Mol. Biol., 16, 629-639.

Zhou, M.Y., Gomez-Sanchez, E.P., Cox, D.L., Cosby, D. \& Gomez-Sanchez, C.E. (1995) Cloning, expression, and tissue distribution of rat nicotinamide adenine dinucleotidedependent $11 \beta$-hydroxysteroid dehydrogenase. Endocrinology, 136, 3729-3734. 